\title{
Retraction
}

\section{Retraction: Lakhani et al. Beneficial Role of HO-1-SIRT1 Axis in Attenuating Angiotensin II-Induced Adipocyte Dysfunction. Int. J. Mol. Sci. 2019, 20, 3205}

\author{
International Journal of Molecular Sciences Editorial Office
}

check for updates

Citation: International Journal of Molecular Sciences Editorial Office. Retraction: Lakhani et al. Beneficial Role of HO-1-SIRT1 Axis in Attenuating Angiotensin II-Induced Adipocyte Dysfunction. Int. J. Mol. Sci. 2019, 20, 3205. Int. J. Mol. Sci. 2021, 22, 10081. https://doi.org/ 10.3390/ijms221810081

Received: 2 September 2021 Accepted: 2 September 2021 Published: 18 September 2021

Publisher's Note: MDPI stays neutral with regard to jurisdictional claims in published maps and institutional affiliations.

Copyright: (C) 2021 by the author. Licensee MDPI, Basel, Switzerland. This article is an open access article distributed under the terms and conditions of the Creative Commons Attribution (CC BY) license (https:// creativecommons.org/licenses/by/ $4.0 /)$.
MDPI, St. Alban-Anlage 66, 4052 Basel, Switzerland; ijms@mdpi.com

The journal retracts the article "Beneficial Role of HO-1-SIRT1 Axis in Attenuating Angiotensin II-Induced Adipocyte Dysfunction" [1], cited above.

Following publication, concerns were brought to the attention of the publisher regarding the figures. The microscopy image for one of the experimental groups in Figure 4A was duplicated, appearing in Figure 1A of another published paper [2]. The authors state this was due to carelessness. Additionally, the actin panel in Figure 2D [1] was similar to Figures 2A and 6E of another published paper [3]. The actin panel in Figure 2B [1] was similar to that in Figure 2 of another published paper [4].

The International Journal of Molecular Sciences Editorial Office has taken the decision to retract the paper. The editor-in-chief approved this retraction.

The authors agree with the retraction.

\section{References}

1. Lakhani, H.V.; Zehra, M.; Pillai, S.S.; Puri, N.; Shapiro, J.I.; Abraham, N.G.; Sodhi, K. Beneficial Role of HO-1-SIRT1 Axis in Attenuating Angiotensin II-Induced Adipocyte Dysfunction. Int. J. Mol. Sci. 2019, 20, 3205. [CrossRef] [PubMed]

2. Bartlett, D.E.; Miller, R.B.; Thiesfeldt, S.; Lakhani, H.V.; Khanal, T.; Pratt, R.D.; Cottrill, C.L.; Klug, R.L.; Adkins, N.S.; Bown, P.C.; et al. Uremic Toxins Activates Na/K-ATPase Oxidant Amplification Loop Causing Phenotypic Changes in Adipocytes in In Vitro Models. Int. J. Mol. Sci. 2018, 19, 2685. [CrossRef] [PubMed]

3. Sodhi, K.; Puri, N.; Favero, G.; Stevens, S.; Meadows, C.; Abraham, N.G.; Rezzani, R.; Ansinelli, H.; Lebovics, E.; Shapiro, J.I. Fructose Mediated Non-Alcoholic Fatty Liver Is Attenuated by HO-1-SIRT1 Module in Murine Hepatocytes and Mice Fed a High Fructose Diet. PLoS ONE 2015, 10, e0128648. [CrossRef]

4. Puri, N.; Arefiev, Y.; Chao, R.; Sacerdoti, D.; Chaudry, H.; Nichols, A.; Srikanthan, K.; Nawab, A.; Sharma, D.; Lakhani, V.H.; et al. Heme Oxygenase Induction Suppresses Hepatic Hepcidin and Rescues Ferroportin and Ferritin Expression in Obese Mice. J. Nutr. Metab. 2017, 2017, 4964571. [CrossRef] 